\title{
Population modelling of Acartia spp. in a water column ecosystem model for the South-Eastern Baltic Sea
}

\author{
L. Dzierzbicka-Glowacka ${ }^{1}$, I. M. Żmijewska ${ }^{2}$, S. Mudrak ${ }^{2}$, J. Jakacki ${ }^{1}$, and A. Lemieszek ${ }^{2}$ \\ ${ }^{1}$ Institute of Oceanology, Polish Academy of Sciences, Sopot, Poland \\ ${ }^{2}$ Institute of Oceanography, University of Gdansk, Gdynia, Poland
}

Received: 9 November 2009 - Published in Biogeosciences Discuss.: 5 January 2010

Revised: 16 June 2010 - Accepted: 16 July 2010 - Published: 21 July 2010

\begin{abstract}
This paper describes numerical simulations of the seasonal dynamics of Acartia spp. in the South-Eastern Baltic Sea. The studies were carried out using a structured zooplankton population model adapted to Acartia spp. The population model with state variables for eggs, nauplii, five copepodites stages and adults was coupled with a marine ecosystem model. Four state variables for the carbon cycle represent the functional units of phytoplankton, pelagic detritus, benthic detritus, and bulk zooplankton, which represent all zooplankton other than the structured population. The annual cycle simulated for 2000 under realistic weather and hydrographic conditions was studied with the coupled ecosystem-zooplankton model applied to a water column in the Gdansk Gulf (South-Eastern Baltic Sea). The vertical profiles of selected state variables were compared to the physical forcing to study differences between bulk and structured zooplankton biomass. The simulated population dynamics of Acartia spp. and zooplankton as one biomass state variable were compared with observations in the Gdansk Gulf. Simulated generation times are more affected by temperature than food conditions except during the spring phytoplankton bloom. The numerical studies are a following step in understanding how the population dynamics of a dominant species in the South-Eastern Baltic Sea interact with the environment.
\end{abstract}

\section{Introduction}

The Baltic zooplankton is composed of microzooplankton, mezozooplankton and macroplankton with characteristic ichtyoplankton forms. The most important species in the Gdansk Gulf are copepoda: Acartia spp. (i.e. A. bifilosa,

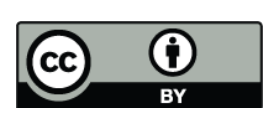

Correspondence to:

L. Dzierzbicka-Glowacka

(dzierzb@iopan.gda.pl)
A. longiremis and A. tonsa), Temora longicornis, Pseudocalanus minutus elongatus and Centropages hamatus and cladocera: Bosmina coregoni maritime and Podon polyphemoides. Copepoda dominate numerically, while in the warm season Cladocera are subdominants. P. m. elongatus occurs in great abundance in the Gdansk Deep, it becomes dominant below $30 \mathrm{~m}$, and is almost the only representative of mesozooplankton below the isohaline layer. In 1999 at the Gdansk Deep, the predominant species were Pseudocalanus minutus elongatus and Acartia longiremis (see Maritime Branch Materials, IMGW 2000).

Copepods are generally considered the most important component in the marine pelagic ecosystem being grazers on phytoplankton and other protists, and prey for animals at higher trophic levels (Mauchline, 1998). Feeding studies of fish larvae by Last (1980) and Wiktor (1990) have shown that Pseudocalanus, Acartia and Temora nauplius and copepodid stages are important components of the diet of numerous species of fish (sprat and herring) in the Baltic Sea and adjacent waters, i.e. the North Sea and also the English Channel, as well as in Scotland, Nova Scotia and Canadian Arctic waters. Our knowledge of their life parameters (e.g. development time, growth rate, and egg production) provides fundamental information on the energy and matter transformation in pelagic food webs.

Most models take into account only nutrients and phytoplankton (Fransz et al., 1991), probably because of the difficulty in representing the complex behaviour that exists among zooplankton species and also among the different zooplankton development stages. Models having one compartment for the whole zooplankton community are useful only for simulating ecosystem dynamics over the course of a few days (Wroblewski and Richman, 1987) or for a stable environment, but become meaningless for long periods if the environment fluctuates. Although field workers consider population dynamics to be the minimum level of study, zooplankton population models are rarely included in ecosystem

Published by Copernicus Publications on behalf of the European Geosciences Union. 
models. A study of copepod population dynamics was performed, for instance, by Carlotii and several co-workers (Carlotti and Sciandra, 1989; Carlotti and Nival, 1992; Carlotti and Radach, 1996; Carlotti and Wolf, 1998). This type of study was carried out for Pseudocalanus spp. by Fennel (2001), Dzierzbicka-Glowacka (2004, 2005a,b), Stegert et al. (2007), and Moll and Stegert (2007). A similar study for Acartia spp. is presented in this paper.

The copepod model for Acartia spp. was calibrated by Dzierzbicka-Glowacka et al. (2009a,b) under the environmental conditions typical of the Southern Baltic Sea. The idea of establishing the combined effect of temperature and food concentration on the development and growth of the naupliar stage and copepodid stages $(\mathrm{C} 1, \mathrm{C} 2, \mathrm{C} 3, \mathrm{C} 4, \mathrm{C} 5$, C6) of Acartia spp. was presented. In this study the development time of copepods Acartia spp. in the changing environmental conditions in the Southern Baltic Sea also was modeled. It is important to investigate and identify the critical factors in mathematical models of pelagic communities with a high-resolution zooplankton (herbivorous copepods) module as a top-down regulator which may play a significant role in marine ecosystems. The aim of this paper is to run the population model within an ecosystem model to study the impact of seasonal variations of food and temperature on Acartia spp. biomass in the South-Eastern Baltic Sea.

\section{Materials and methods}

\subsection{South-Eastern Baltic Sea water column}

The location of interest is a water column in the SouthEastern Baltic Sea close to the P1 station in the open sea, $110 \mathrm{~m}$ water depth, $100 \mathrm{~km}$ from the shore, which is located in the middle of Gdansk Deep (54 $50^{\prime} \mathrm{N} 19^{\circ} 17^{\prime} \mathrm{E}$; Fig. 1). At this depth the water column is characterized by permanent stratification. The halocline, which separates the surface water layer of 7.2 PSU salinity from the deep water layer of $11 \mathrm{PSU}$, is located at a depth of 60-80 m (Voipio, 1981). At deep-water station P1, the isotherm reached its maximum depth in February and March - down to $70 \mathrm{~m}$. In the latter case the isotherm remained until the beginning of May. In April the thermocline began to form; it gradually reached increasingly greater temperature differences and greater depths until the end of July. The layer of colder waters, so called winter water or minimum temperature layer, occurred from February until the end of the year, at a depth of about 50$70 \mathrm{~m}$. The temperature of these waters increased with time from about 0.5 to almost $4{ }^{\circ} \mathrm{C}$, with the range extending both up- and downwards. Near-bottom waters of the Gdansk Deep became gradually colder, from $6^{\circ} \mathrm{C}$ at the beginning of the year to about $4{ }^{\circ} \mathrm{C}$ at the end. All mathematical simulations were performed for conditions characteristic of the P1 station.

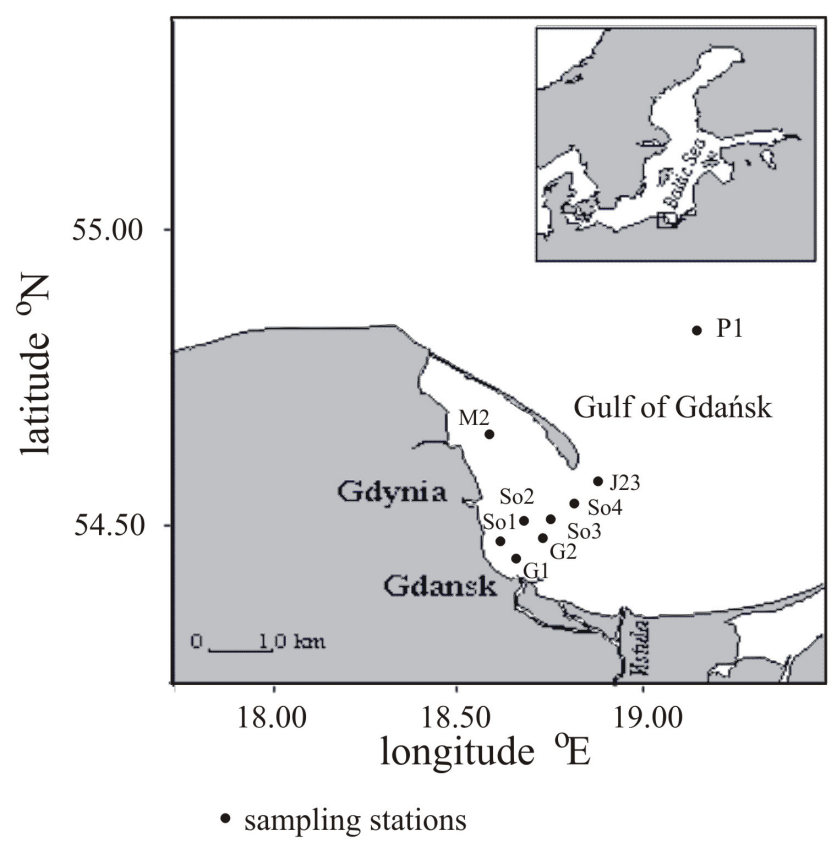

Fig. 1. Location of the sampling stations; full circles - sampling stations.

The summer of 1999 was exceptionally sunny and sweltering. July was warmest month and the monthly average of water temperature in the Gdansk Gulf exceeded $20^{\circ} \mathrm{C}$ and was about $2-3{ }^{\circ} \mathrm{C}$ higher than the long-term mean value. However, in 2000, August was the warmest month and water temperature was similar to the long-term mean value. Temperatures at the stations $(\mathrm{P} 1, \mathrm{~J} 23)$ in the open sea were similar to those at So3, So2 and G2 inside the bay (see Fig. 1). At the end of summer, a decrease in water temperature was faster in the coastal region than in the open sea and in mid-October a sudden cooling of the western coastal water was caused by upwelling, which was still apparent at the end of November.

\subsection{Analytical method}

The plankton material was collected monthly at eight stations in the western part of the Gulf of Gdansk (Fig. 1) from July 1998 till September 2000. Because of absence of some samples (due to meteorological or technical problems), we prepare data for whole year (September 1999August 2000) to observe the seasonal variability of mesozooplankton in this area (Mudrak, 2004). We also analyzed data from three successive summer seasons (July, August and September) of 1998, 1999 and 2000 and from two winter seasons 1998/1999, 1999/2000 (September, January, February and March) to compare interannual changeability of the pelagic community (Mudrak, 2004). Moreover plankton material was collected during 20-25 May 1999 in diurnal cycles from the station P1 (Gdansk Deep) (Fig. 1) in order to investigate short-term variability of mesozooplankton in the water 
column (Mudrak, 2004). Hauls were made using a closing Copenhagen net $(50 \mathrm{~cm}$ diameter, $100 \mu \mathrm{m}$ mesh size) from the water column, which was divided into several layers. At shallow stations not exceeding $10 \mathrm{~m}$ in depth (M2, So1, So2, G1, G2), net hauls were done from the bottom to the sea surface, while at deeper stations $10 \mathrm{~m}$ water layers were sampled separately (So3, So4, J23) (Fig. 1). At P1 station there were layers: $10-0 \mathrm{~m}, 20-10 \mathrm{~m}, 30-20 \mathrm{~m}, 50-30 \mathrm{~m}, 70-50 \mathrm{~m}$, $95-70 \mathrm{~m}$. The biological material collected was preserved with $4 \%$ formaldehyde and every single sample was prepared and analyzed according to HELCOM standard methods in the laboratory (www.helcom.fi). Abundance (in ind. $\mathrm{m}^{-3}$ ) and biomass (in $\mathrm{mg}_{\mathrm{w} . \mathrm{w}} \mathrm{m}^{-3}$ ) for selected species are given by Mudrak (2004). Holoplanktonic organism were determined to the genus or the species, Copepoda nauplii were determined to the species even though this was done rarely in other studies. Due to considerable similarities between young forms within the genus Acartia, species differentiation was only performed on adult forms (Mudrak, 2004). The species Acartia bifilosa was recorded in all samples while the thermophilous A. tonsa appeared from May until November and the psychrophilic A. longiremis was encountered from November until June (Mudrak and Żmijewska 2007).

\subsection{The ecosystem model structure}

Recently, Dzierzbicka-Glowacka (2005b, 2006) developed a one-dimensional, ecosystem, upper layer model: 1-D CEM Coupled Ecosystem Model. This ecosystem model supplemented with the population dynamics submodel for copepods and a component for pelagic detritus was used to study the dynamics of Pseudocalasus minutus elongatus in the Southern Baltic Sea (Dzierzbicka-Glowacka, 2005a,b). The 1-D CEM model reduced to a 1-D POC Particulate Organic Carbon Model with an equation for dead organic matter (pelagic detritus) is presented in Dzierzbicka-Glowacka et al. (2010). The 1-D POC model is an ecosystem model able to simulate biogeochemical processes in the physical environment. The particulate organic carbon (POC) concentration was determined as the sum of phytoplankton and zooplankton biomasses and pelagic detritus concentrations.

The marine ecosystem model consists of a set of equations. These are all of the general form, i.e. equations of the diffusion type including the functions of gains and losses, expressing change in the pelagic variables. The temporal changes in the phytoplankton biomass are caused by primary production, excretion, mortality, grazing by zooplankton and sinking. The zooplankton biomass is affected by ingestion, excretion, faecal production, mortality, and carnivorous grazing. The changes in the pelagic detritus concentration are determined by input of: dead phytoplankton and zooplankton, natural mortality of predators, faecal pellets, and sinks: sedimentation, zooplankton grazing and decomposition. In this model nutrients are represented by two components: total inorganic nitrogen $\left(\mathrm{NO}_{3}^{-}+\mathrm{NO}_{2}^{-}+\mathrm{NH}_{4}^{+}\right)$and phosphate $\left(\mathrm{PO}_{4}^{3-}\right)$.
Silica is not included, as it is not a critical parameter for the primary production, yet. In this paper bacteria were not explicitly simulated. Their activity only appeared implicitly in the parameterizations of the remineralization terms. Benthic detritus accumulated by sinking out of the water column, it was regenerated by bacterial action, and the resulting nutrients move upwards by turbulent diffusion. Bacteria will be considered in our next studies in which the dissolved organic carbon DOC will be modeled.

The different sinks and sources for 1-D POC model are put together in Table 1 in Dzierzbicka-Glowacka et al. (2010), while the mathematical formulation for biogeochemical processes in the model is presented in Appendix A-C in Dzierzbicka-Glowacka (2005b) and Dzierzbicka-Glowacka et al. (2010). Results obtained by Dzierzbicka-Glowacka et al. (2010) indicated that the 1-D POC model might be a useful tool for actual carbon cycle and pelagic variables investigations and prediction of theirs changes. Calibration of the model and comparison of model results with measurements for temperature and the phytoplankton biomass and nutrients concentration in 1995-2000 are given in a paper Dzierzbicka-Glowacka et al. (2010). With respect to all the parameters, the correlations of the observed regularities decreased from the surface to the bottom. The correlations for the layers from the surface down to $50 \mathrm{~m}$ for Nutrp and to $60 \mathrm{~m}$ for Nutr $_{\mathrm{N}}$ were quite good $(>0.7)$ during late winter and autumn and down to $40 \mathrm{~m}(>0.6)$ in summer. The simulated phytoplankton biomass was compared with those and chlorophyll- $a$ concentration measured in the $10 \mathrm{~m}$ layer as average value including carbon to chlorophyll a ratio in phytoplankton in the Gdansk Gulf in the $0-15 \mathrm{~m}$ layer after Witek (1993). The simulation of phytoplankton was the weakest, despite a correlation coefficient of 0.61 . The consistency of the calculated values with those measured in the vertical distribution was particularly good with regard to temperature. This results also testifies to the fact that the environmental conditions did not change radically and that the applied various processes were regular. As well comparison of measured and modeled POC (POC $=$ Phyt + Zoop + DetrP) and pelagic variables Phyt and Zoop concentrations in 2007 confirm appropriate functioning of the model (Fig. 2).

The flow field and water temperature used as the inputs in the ecosystem model, were reproduced by the 3-D hydrodynamical model IOPAS-POPCICE, which is now running for the period 1960-2000 (see project ECOOP IP WP10). The model was forced using daily-averaged reanalysis and operational atmospheric data (ERA-40) that were derived from the European Centre for Medium-range Weather Forecast (ECMWF). The interpolated output of the hydrodynamical model was used as the input in the ecosystem+copepod model, since in the simulated area the dynamical characteristics remain almost unchanged in a horizontal plane in comparison to vertical changes. Hence, the magnitudes of the lateral import/export are lower, and the above assumption can be made. 
Table 1. Parameter values for Acartia spp. in the presented model. Source: (1) Ambler (1985), (2) Dzierzbicka-Glowacka et al. (2009), (3) Norrbin (1996), (4) Stegert et al. (2007), (5) in this paper and (6) see Fig. 3 in this paper.

\begin{tabular}{|c|c|c|c|}
\hline Symbol & Value & Parameter & Source \\
\hline Food $_{\mathrm{o}}$ & $\begin{array}{l}10 \mathrm{mg} \mathrm{C} \mathrm{m}^{-3}(\mathrm{~N} 3-6, \mathrm{C} 1-2) \\
20 \mathrm{mg} \mathrm{C} \mathrm{m}^{-3}(\mathrm{C} 3-6)\end{array}$ & minimal threshold food concentration & (2) \\
\hline$K_{\text {Food }}$ & $\begin{array}{l}28 \mathrm{mg} \mathrm{C} \mathrm{m}^{-3}(\mathrm{~N} 3-\mathrm{N} 6) \\
70 \mathrm{mg} \mathrm{C} \mathrm{m}^{-3}(\mathrm{C} 1-\mathrm{C} 6)\end{array}$ & half-saturation constant & (2) \\
\hline$K_{1}$ & 1.3 & power coefficient & (5) \\
\hline$K_{2}$ & $\begin{array}{l}4 \text { (N3-6, C1-6) } \\
6 \text { (eggs-N2) }\end{array}$ & power coefficient & (4) \\
\hline$n_{\mathrm{a}}$ & 0.7 & assimilation efficiency & (2) \\
\hline$n_{\mathrm{f}}$ & 0.3 & egestion & (2) \\
\hline$n_{\mathrm{e}}$ & 0.3 & active metabolism & (2) \\
\hline$n_{\mathrm{W}}$ & $\begin{array}{l}0.2 \mathrm{~d}^{-1}(\mathrm{~N} 1-\mathrm{N} 2) \\
0.04 \mathrm{~d}^{-1}(\mathrm{~N} 3-6, \mathrm{C} 1-6)\end{array}$ & basic metabolism & (5) \\
\hline$p_{\text {Phyt }}$ & 0.6 & preference phytoplankton & (5) \\
\hline$p_{\text {Zoop }}$ & 0.15 & preference microzooplankton & (5) \\
\hline$p_{\text {Detr }}$ & 0.25 & preference small detritus & (5) \\
\hline$Q_{10}$ & 2.6 & parameter ingestion & (6) \\
\hline$t_{1}$ & 0.239 & temperature coefficient & (6) \\
\hline$t_{2}$ & 1.1 & temperature coefficient & (6) \\
\hline$T_{\mathrm{O}}$ & $18^{\circ} \mathrm{C}$ & reference temperature & (5) \\
\hline$t_{3}$ & 0.6 & slope factor & (5) \\
\hline$W_{\text {egg }}$ & $0.0305 \mu \mathrm{g} \mathrm{C} \mathrm{egg}^{-1}$ & weight of egg & (1) \\
\hline$X$ & 0.5 & sex ratio & (5) \\
\hline$\alpha_{e}$ & -8.701 & temperature coefficient & (3) \\
\hline$a$ & 1008 & population specific constant & (3) \\
\hline$b$ & -2.05 & slope of the line $D_{\mathrm{e}}$ & (3) \\
\hline
\end{tabular}

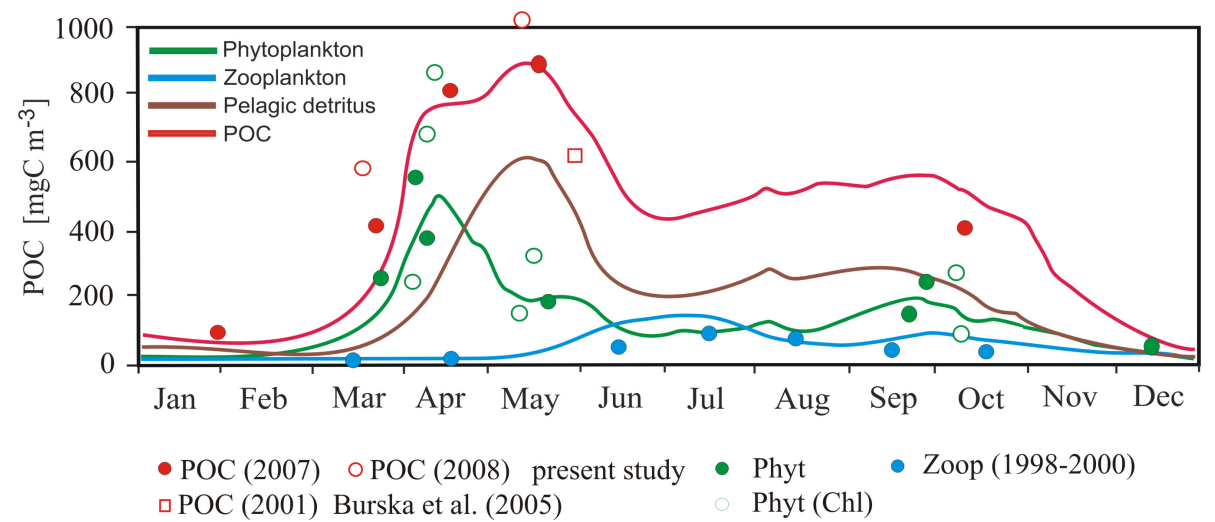

Fig. 2. Modeled POC seasonality presented against background of Phyt, Zoop and DetrP and in situ measured POC concentrations in the surface layer; solid line - POC, dashed line - phytoplankton, dash-dotted line - zooplankton, dotted line - pelagic detritus, full circles data of POC from 2007, open circles - data of POC from 2008 (Dzierzbicka-Glowacka et al., 2010), open square - data of POC from 2001 (Burska et al., 2005). The same scale for all the variables $\left(\mathrm{mg} \mathrm{C} \mathrm{m}^{-3}\right)$.

\subsection{Copepod model for Acartia spp.}

The copepod model (Dzierzbicka-Glowacka, 2009a) includes here the rate of transfer from stage $i$ to the next $(i+1)$. It consists of sixteen state variables with masses $W_{i}$ and numbers $Z_{i}$ for each of eight model stage, grouping stages to: the non feeding stages and eggs are represented by the stage - eggs $-\mathrm{N} 2$, following are the naupliar stages $-\mathrm{N} 3-\mathrm{N} 6$, then five copepodite stages $-\mathrm{C} 1, \mathrm{C} 2, \mathrm{C} 3, \mathrm{C} 4, \mathrm{C} 5$ and finally the adult stage $-\mathrm{C} 6$. For the each of eight model stage, mass 

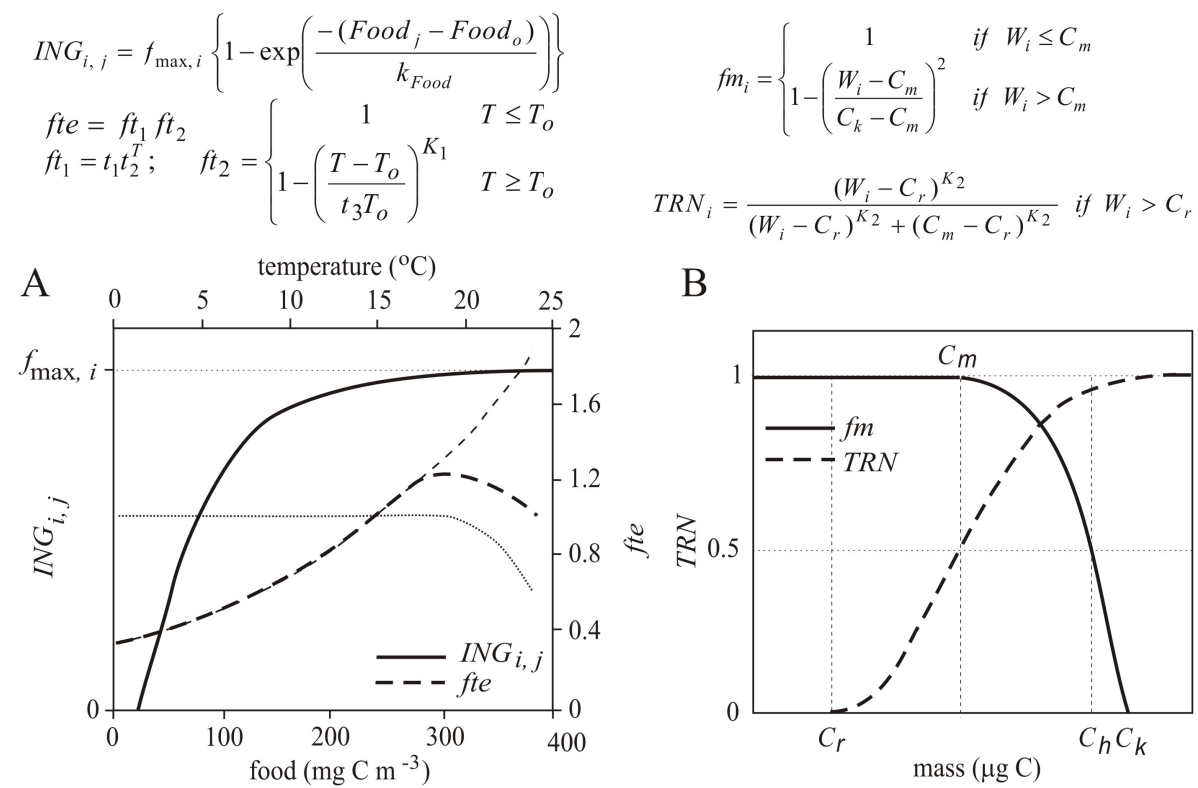

B

where: $f_{\max }$, Food $_{o}, k_{\text {Food }}, C_{k}, C_{r}$ - Dzierzbicka-Glowacka et al. (2009a)

$t_{1}=0.239, t_{2}=1.1, T_{0}=18^{\circ} \mathrm{C}, K_{1}=1.3, t_{3}=0.6 \quad K_{2}=4$ (nauplii, copepodites, adults)

$K_{2}=6$ (eggs)

Fig. 3. Diagrams of three parameters (Food, $T, W$ ) used in the copepod model for physiological process rates: ingestion rate depending on food availability - solid line, (A), temperature - dashed, (A) - and weight - solid line, (B) - and transfer depending on weight - dashed, (B).

$W_{i}$ and number $Z_{i}$ were calculated. The parameter values for Acartia spp. used in the presented model are given in Table 1 .

The changes in the stage-specific mean biomass, which is the algebraic sum of the products of the masses, $W_{i}$, and numbers, $Z_{i}$, of Acartia spp. for each of the model stages, are controlled by ingestion, egestion, metabolism, mortality, predation and transfer. Both processes, ingestion and transfer, depend on individual weights in successive stages using critical moulting masses, $C_{m}$, as described by Carlotti and Sciandra (1989). In this paper, the critical moulting mass is obtained by: $C_{m}=\left(C_{k}+\sqrt{2} C_{r}\right) /(1+\sqrt{2})$, assuming that the half saturation value is equal $C_{h}=2 C_{m}-C_{r}$ (Moll and Stegert, 2007), which ensures that ingestion is not reduced before transfer starts and that the function $\mathrm{fm}_{i}$ describing the limitation of ingestion rate as molting weight is $f m_{i}\left(C_{h}\right)=0.5$ (Fig. 3b). The transfer rate $\mathrm{TRN}_{i}$ from stage $i$ to the next $i+1$ is given by a sigmoidal function depending on the $W_{i}$ and $C_{m}$ with a reference weight, $C_{r}$, as a threshold mass, below which no transfer takes place and $\mathrm{TRN}_{i}\left(C_{m}\right)=0.5$ (Fig. 3b). This was not included in previous versions of the model (Dzierzbicka-Glowacka, 2005; Dzierzbicka-Glowacka et al., 2009a). The reference $C_{r}$ and critical $C_{k}$ masses are defined for each stage. The values of $C_{r}$ and $C_{k}$ derived from literature data (Ciszewski and Witek, 1977), were used for the weight-dependent function of ingestion.
The ingestion rate $\mathrm{ING}_{i}$ for specific developmental stages is dependent firstly on the maximum ingestion rate, secondly on available food Food $_{j}$ (Fig. 3a), thirdly on temperature $T$, following a constant $Q_{10}$ (2.6) law (Fig. 3a) applicable to the temperature range of $5-18{ }^{\circ} \mathrm{C}$ and fourthly on individual weight using $C_{m}$ by the function $f m_{i}$ (Fig. 3b). $\mathrm{Q}_{10}$ was used to estimate the $t_{2}$ coefficient; consequently, the parameter $t_{2}$ had a value of 1.1. Coefficient $t_{1}$ was calculated so that fte was equal to 1 at $15^{\circ} \mathrm{C}$ and, therefore, $t_{1}$ was equal to 0.239 . Coefficients $t_{1}$ and $t_{2}$ were identical for all stages. Additionally, a parabolic threshold function $f t_{2}$ (with $T_{0}=18^{\circ} \mathrm{C}, t_{3}=0.6$ and $K_{1}=1.3$ ) realizes a decrease at higher temperatures as a result of physiological depression. So, growth follows an exponential curve up to the optimal temperature of $\sim 18^{\circ} \mathrm{C}$ and decreases for higher temperatures. Moulting to the next stage occurs when the critical moulting weight has been reached. During the molting process a small proportion of the weight is lost (Carlotti and Wolf, 1998). The food concentration Food $_{j}$ (equaling $p_{\text {Phyt }}=60 \%$ of phytoplankton biomass, $p_{\mathrm{Zoop}}=15 \%$ of microzooplankton biomass and $p_{\text {DetrP }}=25 \%$ of pelagic detritus concentration) for each stage $i$ in this study is included:

$$
\mathrm{ING}_{i}=\sum_{j=1}^{3} \mathrm{ING}_{i, j} \text { fte fmi } W_{i} p_{j}
$$

with $\mathrm{ING}_{i, j}=f_{\text {max }, i}\left\{1-\exp \left(\frac{-\left(\text { Food }_{j}-\text { Food }_{0}\right)}{k_{\text {Food }}}\right)\right\}$ and $\sum p_{j}=1$. 
The ingested food is portioned into growth and metabolic losses of respiration, excretion, and egestion and additionally for the population in moulting and reproduction.

The assimilation rate of $70 \%$ is generally considered as representative for copepods; hence the percentage of ingestion egested as fecal material, which immediately enter the detritus pool is $30 \%$. Nauplii $\mathrm{N} 1$ and $\mathrm{N} 2$, which do not feed, are assumed to consume $20 \%$ of their weight per day for basic metabolism. For nauplii from N3 to N6, copepodites and adults, were assigned a minimum respiration rate of $4 \%$ of their weight per day, to which was added a respiration rate equal to $30 \%$ of the ingestion rate for active metabolism (see Dzierzbicka-Glowacka et al., 2009a). The ingestion rate decreases as weight reaches the critical weight of molt, because growth is limited by the exoskeleton. Here, it is assumed that the ingestion in one stage follows a negative parabolic function $f m_{i}$ when the weight exceeds the critical molting weight of stage $i$. Such a limitation does not occur in adults for which reproduction limits weight increase (see Carlotti and Sciandra, 1989).

In this study, the hypothesis that the food-saturated rate of production of egg matter is equivalent to the maximal specific growth rate of copepods was used for calculation of the number of eggs produced by each female during one day (Sekiguchi et al., 1980; McLaren and Leonard, 1995). The egg production rate was obtained as a function of growth rate, i.e. by multiplying exp GROWTH -1 by $W_{\text {female }} / W_{\text {egg }}$, assuming the growth rate to be that of the naupliar stage (Dzierzbicka-Glowacka et al., 2009b) and including here a transfer from adults to eggs. The number of juveniles is defined on the assumption that eggs are released by the adult female throughout some time span, $J$. The period of egg production for females of Acartia bifilosa from the South-Eastern Baltic Sea varied with temperature from about 14 days at $20^{\circ} \mathrm{C}$ up to about 1 month at $7^{\circ} \mathrm{C}$ (Ciszewski and Witek, 1977). The efficiency term, $X(=50 \%)$, was the conversion of biomass increase by the adult population into eggs, including the wasted growth in males. In this study the weight of an egg $W_{\text {egg }}$ was taken to be $0.0305 \mu \mathrm{g} \mathrm{C} \mathrm{egg}^{-1}$ for Acartia (Ambler, 1985). In the present study, the embryonic duration $D_{\mathrm{e}}$ is estimated after Norrbin (1996) for A. longiremis which is similar to $D_{\mathrm{e}}$ of $A$. clausi (McLaren, 1978). Hence, the parameters of Belehrádek's function $a$ and $\alpha_{e}$ were determined as $a=1008$ and $\alpha_{e}=-8.701$, where $a$ is a population specific constant, and $\alpha_{e}$ is related to the normal temperature regime for the species.

The mortality of Acartia tonsa in the southern Baltic Sea, ca. $7 \%$ in winter, $5 \%$ in autumn, and negligible in summer and spring (ca. 1\%) was found by Schmidt et al. (1998). We use the above value for Acartia spp. Here the migration process, only for copepodids in the vegetation season, was described in a day-night cycle (see Dzierzbicka-Głowacka, 1994; Dzierzbicka-Głowacka et al., 2006) according to the data given by Mudrak (2004).
In the Calanoida, dormancy occurs either in the embryonic stage (resting eggs) or in the copepodid stage. In coastal and fresh waters, dormancy is expressed by benthic resting eggs; in the deep oceanic waters many species over-winter as a dormant copepodid stage $(\mathrm{C} 4 / 5)$ that descends to the depths. Diapause as well as quiescence occurs, although the type of dormancy has not been determined in all studies. The study conducted by Katajisto (2006) in northern Baltic Sea, where Acartia bifilosa is the most abundant species of the pelagic mesozooplankton community, provides that A. bifilosa produces only one type of egg - subitaneous eggs (Viitasalo, 1992; Katajisto, 2006). In this paper, the dormancy of the modeled stages was not included in the calculations. The simulation starts with over-wintering adults.

\section{Results}

This model described above was used in the numerical simulations of the seasonal dynamics of Acartia spp. in the SouthEastern Baltic Sea (Gdansk Deep). The simulation was carried out for 2000, when observations from several months including winter values, were available. The correlation of physical forcing and biological response of the main ecosystem state variables is shown in Fig. 4.

Modeled temperature fields resulting from the physical model (as the output) (Fig. 4a) were used for the biogeochemical processes calculation. The simulated temperature began to increase at the end of March after day 88 and reached $\sim 18{ }^{\circ} \mathrm{C}$ in August. At the same time (March), vertical diffusion decreased (Fig. 4b). This led to thermal stratification, causing a high gradient within $30-40 \mathrm{~m}$ for most state variables. This stratification broke in September/October (day 273) with increasing vertical exchange. The destruction of the thermocline started in the late autumn. The depths of the upper layer, which were determined by the mixing intensity in the water column, showed that strong gradients in the nutrient concentration develop (Fig. $4 \mathrm{c}$ and d). The spring bloom in 2000 was triggered in mid-March, most likely. The bloom was initiated by the heating event and the extremely low winds. The end of permanent overturning of the water column in mid-March was the main cause that allowed the phytoplankton to start growing. The phytoplankton biomass reflected the nutrient availability, showing a strong nutrientdepleting spring bloom. The phytoplankton biomass was the highest in the surface layers and reached maximum in midApril (day 101) with a peak of $450 \mathrm{mg} \mathrm{C} \mathrm{m}^{-3}$. Correlated with the phytoplankton bloom, nutrient depletion began and limited plankton growth. The phytoplankton biomass was low in summer (July and August) most likely as a result of faster depletion of nutrients and the phytoplankton grazing by zooplankton.

The development of zooplankton followed the development of both phytoplankton and pelagic detritus. The start of the zooplankton increase took place in May, about six weeks 

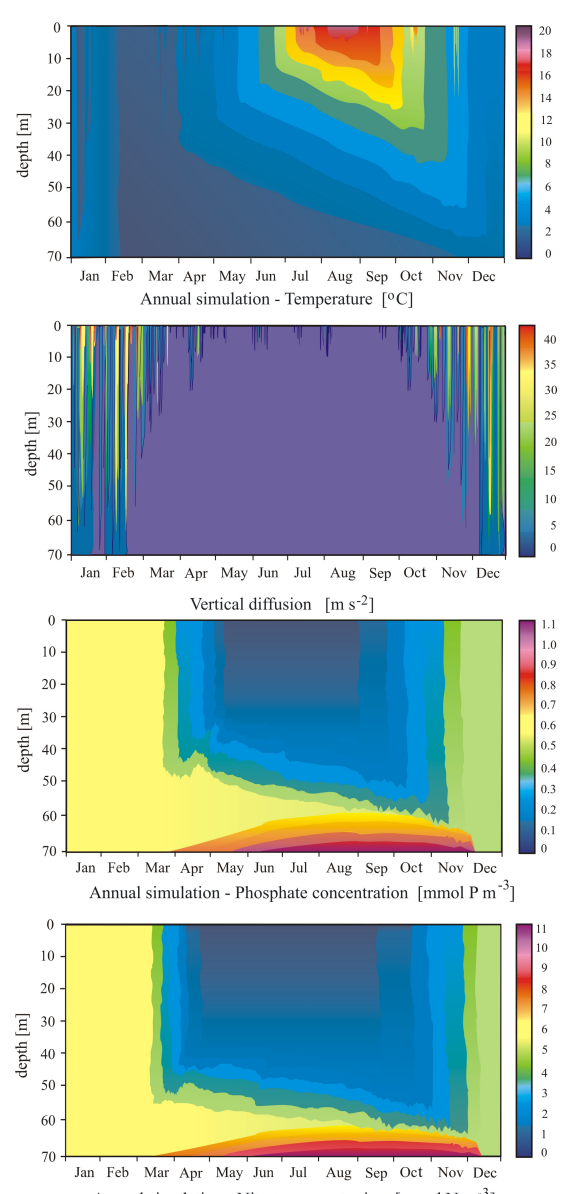

Annual simulation - Nitrate concentration $\left[\mathrm{mmol} \mathrm{N} \mathrm{m}^{-3}\right]$

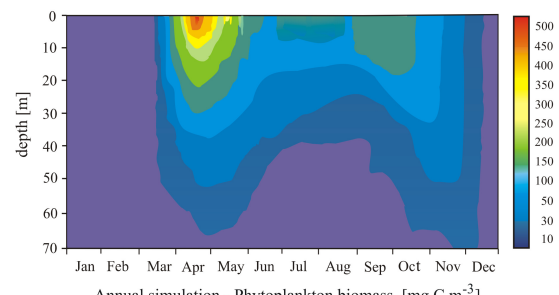

Annual simulation - Phytoplankton biomass $\left[\mathrm{mg} \mathrm{C} \mathrm{m}^{-3}\right.$ ]
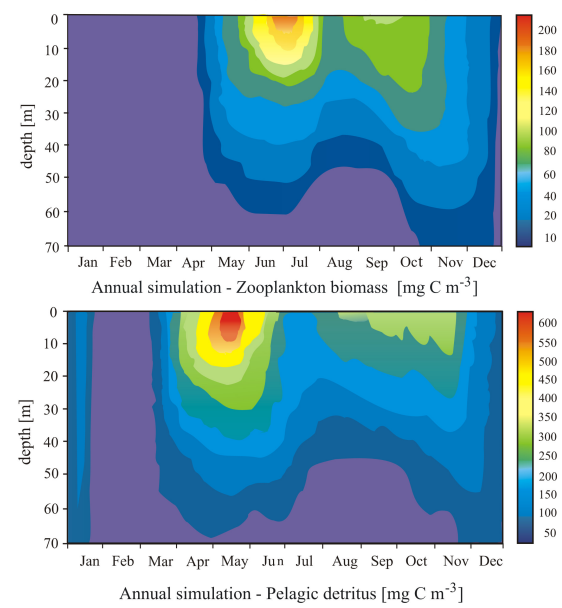

Fig. 4. Model results for physical and biological state variables. after the beginning of the spring bloom. Biomass of zooplankton was characterized by the occurrence of two biomass peaks in a year, the main one - at the turn of June and July (ca. $160 \mathrm{mg} \mathrm{C} \mathrm{m}^{-3}$ ), and a smaller one, in August/September (ca. $100 \mathrm{mg} \mathrm{C} \mathrm{m}^{-3}$ ), (Fig. 4f). Pelagic detritus (Fig. 4g) was abundant mainly when the phytoplankton concentration exceeded $200 \mathrm{mg} \mathrm{C} \mathrm{m}^{-3}$, and its maximum concentration (ca. $590 \mathrm{mg} \mathrm{C} \mathrm{m}^{-3}$ ) was in the near surface layers. Detritus served as a zooplankton food source within the whole column during spring and autumn and was sinking through the water column supplying material to the bottom detritus pool. In early autumn a certain increase in phytoplankton biomass took place. It might have been related to an increase in the concentration of nutrients resulting from deeper mixing of the water column. The vegetation season ended in December, when the biomass of phytoplankton dropped to the starting level from January-February.

\subsection{Acartia spp.}

The vertical distributions shown in Fig. 5 demonstrate the annual biomass profiles for the selected state variables representing Acartia spp. stage dynamics. The four state variables for eggs: N2, naupliar stage, N3-N6, copepodite stage, C1C5 (including five copepodite stages together) and finally the adult stage, C6 are presented. First, eggs occurred at the end of March according to the phytoplankton spring bloom and increasing temperature.

Several generation peaks within the stage biomass variables can be observed during the development period of Acartia spp. throughout the year. The development assembles in the column water - mainly in the euphotic layer, where food - a mixture of phytoplankton, microzooplankton and small pelagic detritus - is available but also extends beyond the thermocline due to ingestion of dead organic matter. The highest proportion of all the developmental stages is found above the thermocline. In June a thermocline developed at a depth of $30 \mathrm{~m}$; the temperature in the surface layer increased from $13{ }^{\circ} \mathrm{C}$ in June to $17^{\circ} \mathrm{C}$ in July and $18.5^{\circ} \mathrm{C}$ in August, before cooling started. In November the thermocline was destroyed. During the same time, most of the total biomass of Acartia spp., as the sum over four state variables, non-feeding, naupliar, copepodite and adult stages, is observed.

Figure 6 presents the simulated stage biomasses, which are the algebraic sum of the products of the weights, $W_{i}$, and numbers, $Z_{i}$, of each stage, as vertical mean values and also the number of Acartia spp. generations in the South-Eastern Baltic Sea (Gdansk Deep) is illustrated. The simulation starts with over wintering copepodtes $\mathrm{C} 4$ and $\mathrm{C} 5$ and adults. The small maxima occurring in the distribution of the eggs - N2 stage are the result of a brood by successive females causing their numbers to increase. The strong increase in an available food concentration - mainly of phytoplankton biomass, in the spring bloom begins egg production. 

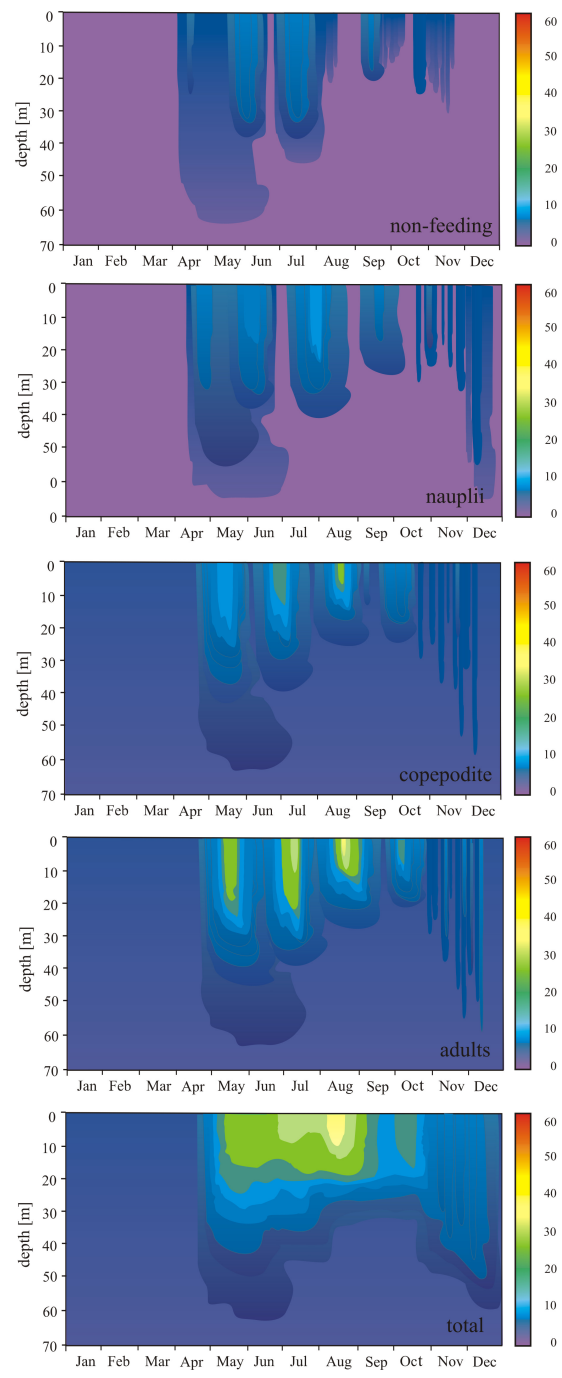

Fig. 5. Simulated annual profiles of four Acartia spp. groups representing: biomasses of eggs, nauplii, copepodites and adults and of total biomass of Acartia spp. $\left(\mathrm{mg} \mathrm{C} \mathrm{m}^{-3}\right)$.

The hatching time at $4-6{ }^{\circ} \mathrm{C}$ is $20 \mathrm{~d}$. Five complete distinct generations, from eggs to adults, developed throughout the year, the first beginning in mid-March. The stage duration for the first generation is $65 \mathrm{~d}$. The development time of all the model stages was obtained by equation (4) given in Dzierzbicka-Glowacka at el. (2009a). During development of the second generation (51 d), surface temperature increases from 8 to $15^{\circ} \mathrm{C}$ causing accelerated growth, while a drop in food concentration causes a retard. The third generation starts in the first half of July (day 191) and takes $47 \mathrm{~d}$ to complete as a result of the low food concentration (ca. $70 \mathrm{mg} \mathrm{C} \mathrm{m}^{-3}$ in the upper $20 \mathrm{~m}$ layer) and the high surface temperature $\left(15-18.5^{\circ} \mathrm{C}\right)$. The total development time for the next generation is the shortest and assumes the value of $45 \mathrm{~d}$ similar to that of the third generation. During the fourth generation, temperature is lower,

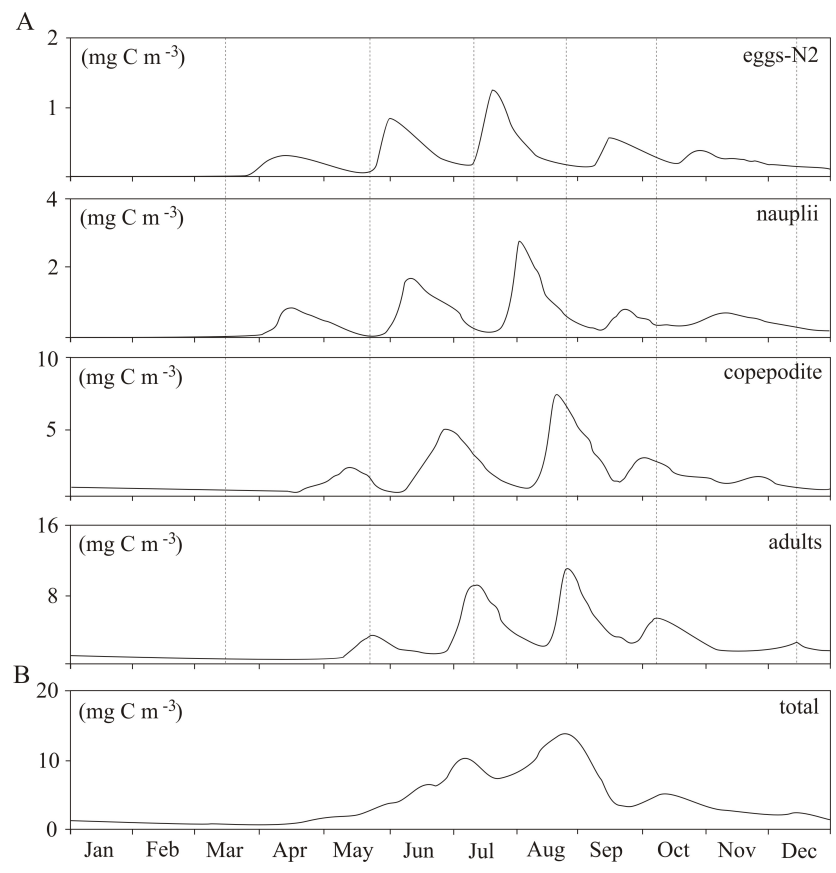

Fig. 6. Simulated Acartia spp. generations (A) vertical mean biomasses of eggs, nauplii, copepodites and adults $\left(\mathrm{mg} \mathrm{C} \mathrm{m}^{-3}\right)$, (B) total biomass as vertical mean concentrations.

with a mean of ca $2.5^{\circ} \mathrm{C}$, than during the previous generation but the food supply concentration is higher, mean value of Food $=120 \mathrm{mg} \mathrm{C} \mathrm{m}^{-3}$ in the $50 \mathrm{~m}$ water column. This is equal to the surface value as a result of vertical mixing. Individuals of the fifth generation (day 283) are produced in the first half of October and reach adulthood at the end of the numerical simulation when there is a lack of food and a decrease in temperature.

The distribution shown in Fig. $6 \mathrm{~b}$ presents the vertical mean total biomass, which is the algebraic sum of the vertical mean biomasses of all stages. The total biomass of Acartia spp. is characterized by one main biomass peak at the end of August, and two smaller peaks. The first is slightly smaller, occurring during in the first half of July and the second small peak occurs in mid-October. The peak of biomass in $\mathrm{Au}-$ gust (ca. $15 \mathrm{mg} \mathrm{Cm}^{-3}$ ) is mainly due to the high biomass of copepodites and adults of the third generation and the high egg production as a result of the very high numbers of adults of the previous generation. The high reproduction is a result of high temperature at this time. The smaller peaks of biomass (ca. $11 \mathrm{mg} \mathrm{C} \mathrm{m}^{-3}$ and $5 \mathrm{mg} \mathrm{C} \mathrm{m}^{-3}$, respectively) also are mainly due to the high biomass of copepodites and adults of the 2nd and 4th generations and the high egg production of the 1st and 3rd generations, respectively. However, the nauplii biomass of successive generations influence the peaks of the total biomass at the beginning of the growth.

The phytoplankton peak in September-October permits a new growth period for the 4th generation and females of this 
Table 2. Total biomass of Acartia spp. (in $\mathrm{mg}_{\mathrm{w} . \mathrm{w} .} \mathrm{m}^{-3}$ ) as monthly averages in the surface (0-20 m) layer in the summer season (July, August, September) in 1998, 1999 and 2000 from the eight stations in the Gdansk Gulf (see Mudrak, 2004).

\begin{tabular}{lccc}
\hline \multicolumn{4}{c}{ Total biomass of Acartia spp. $\left(\right.$ in $\mathrm{mg}_{\mathrm{w} . \mathrm{w} .} \mathrm{m}^{-3}$ ) } \\
\hline station & July $1998 / 1999 / 2000$ & August $1998 / 1999 / 2000$ & September $1998 / 1999 / 2000$ \\
\hline J23 & $30 / 20 / 50$ & $80 / 8 / 450$ & $30 / 30 / 35$ \\
So1 & $65 / 70 / 160$ & $10 / 70 / 50$ & $20 / 60 / 10$ \\
So2 & $10 / 45 / 40$ & $10 / 40 / 120$ & $70 / 30 / 50$ \\
So3 & $15 / 70 / 60$ & $15 / 20 / 100$ & $25 / 5 / 10$ \\
So4 & $20 / 270 / 40$ & $50 / 10 / 40$ & $5 / 5 / 15$ \\
G1 & $5 / 300 / 90$ & $20 / 80 / 400$ & $20 / 60 / 10$ \\
G2 & $5 / 130 / 50$ & $15 / 60 / 380$ & $10 / 20 / 5$ \\
M2 & $10 / 40 /-$ & $15 / 20 / 30$ & $10 / 40 / 20$ \\
\hline
\end{tabular}

generation produce relatively small eggs to give a 5 th generation in October-November.

\subsection{Experimental data}

The structure of mezozooplankton in the Gdansk Gulf in 2000 mainly consisted of four taxa: copepoda, cladocera, rotatoria and meroplankton; but in summer, biomass of cladocera was three times as high as copepod biomass (Mudrak, 2004). The predominant species were Acartia bifilosa during the entire year and Bosmina coregoni maritime in summer (Mudrak, 2004).

In the Gdansk Gulf, cladocera only occurs from May to August; the other three taxa of mezozooplankton: copepoda, rotatoria and meroplankton in 1999 and 2000 occurred in different proportions during the whole year. From September to April, copepods dominated assuming 75-96\% of total biomass mezozooplankton. In the period from May to $\mathrm{Au}-$ gust, the dominant groups were: in May - rotatoria (56\%), June - cladocera (53\%), July - copepoda (77\%) and in August - cladocera (66\%) (Mudrak, 2004). Proportional participation of copepoda in mezozooplankton, outside the dominant month, was not large - from $20 \%$ in June (min) to $32 \%$ in August (see Fig. 7). Copepoda accounted for $24 \%$ of total mezozooplankton biomass in the entire area of Gdansk Gulf, and exceeded 50\% in the region of Puck Lagoon (M2) only.

The dominant part on score of copepoda biomass with exception in November and June played Acartia spp. They reached a maximum $(98 \%)$ in September and minimum (23\%) in June. However, in months of copepoda dynamic development, this participation reduces overbalance of Temora longicornis (in November - 52\% and June - 66\%) and in a less degree, Centropages hamatus $(11 \%)$ and Eurytemora sp. $(5 \%)$ in the coastal waters and Pseudocalanus minutus elongatus $(15 \%)$ in the deep regions of the Gdansk Gulf (see Fig. 8).

The monthly averages of Acartia spp. biomass (in $\mathrm{mg}_{\mathrm{w} . w}$. $\mathrm{m}^{-3}$ ) in the summer season (July, August, September) in
1998, 1999 and 2000 from the eight stations in the Gdansk Gulf (see Fig. 9) are given in Table 2. Analysis of the data set and in Mudrak (2004) showed that mesozooplankton concentration varied characteristically, being dependent on abiotic indicators of the environment.

In 2000 at the all stations, biomass of Acartia spp. was relatively high. The highest values occurred in August at J23 (ca. $450 \mathrm{mg}_{\mathrm{w} . w .} \mathrm{m}^{-3}$ ), G1 (ca. $400 \mathrm{mg}_{\mathrm{w} . w .} \mathrm{m}^{-3}$ ) and

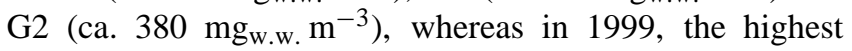
biomass occurred in July at the all stations, i.e. at So4 (ca. $270 \mathrm{mg}_{\mathrm{w} . \mathrm{w} .} \mathrm{m}^{-3}$ ) and G1 (ca. $300 \mathrm{mg}_{\mathrm{w} . w .} \mathrm{m}^{-3}$ ). However, in 1998 at the all stations, biomass of Acartia spp. was relatively low. The highest values were noted in July at So1 (ca. $65 \mathrm{mg}_{\mathrm{w} . \mathrm{w} .} \mathrm{m}^{-3}$ ), August at $\mathrm{J} 23$ (ca. $80 \mathrm{mg}_{\mathrm{w} . w .} \mathrm{m}^{-3}$ ) and in September at So2 (ca. $70 \mathrm{mg}_{\mathrm{w} . w .} \mathrm{m}^{-3}$ ) - see Fig. 9 (biomass in $\mathrm{mg} \mathrm{C} \mathrm{m}^{-3}$ ). At the stagnation time, biomass of Acartia spp. was from $1-3 \mathrm{mg}_{\mathrm{w} . \mathrm{w}} \mathrm{m}^{-3}$ in February, 3$5 \mathrm{mg}_{\mathrm{w} . \mathrm{w}} \mathrm{m}^{-3}$ in March to $4-6 \mathrm{mg}_{\mathrm{w} . \mathrm{w}} \mathrm{m}^{-3}$ in November. During May 1999 in the Gdansk Deep, the vertical distributions of observed biomass in diurnal cycles were different, i.e. $0.02-1 \mathrm{mg} \mathrm{C} \mathrm{m}^{-3}$ in the upper layer and $0.03-$ $0.55 \mathrm{mg} \mathrm{C} \mathrm{m}^{-3}$ in the lower layer for Acartia spp. The average value of the biomass in the whole column water at this time was $0.395 \mathrm{mg} \mathrm{C} \mathrm{m}^{-3}$ for Acartia spp.

\section{Discussion}

The simulation provided the development of four zooplankton model stages (Fig. 6) and additionally the total biomass as summed over all stages. The total biomass of Acartia spp. is compared to the total zooplankton biomass, which was modeled using the bulk formation. The simulations show the general variations in investigated populations with time (Fig. 5). The results show significant changes in phytoplankton biomass distribution, which took place in an area where there was a considerable increase in primary production. During the spring bloom, there is a substantial growth 


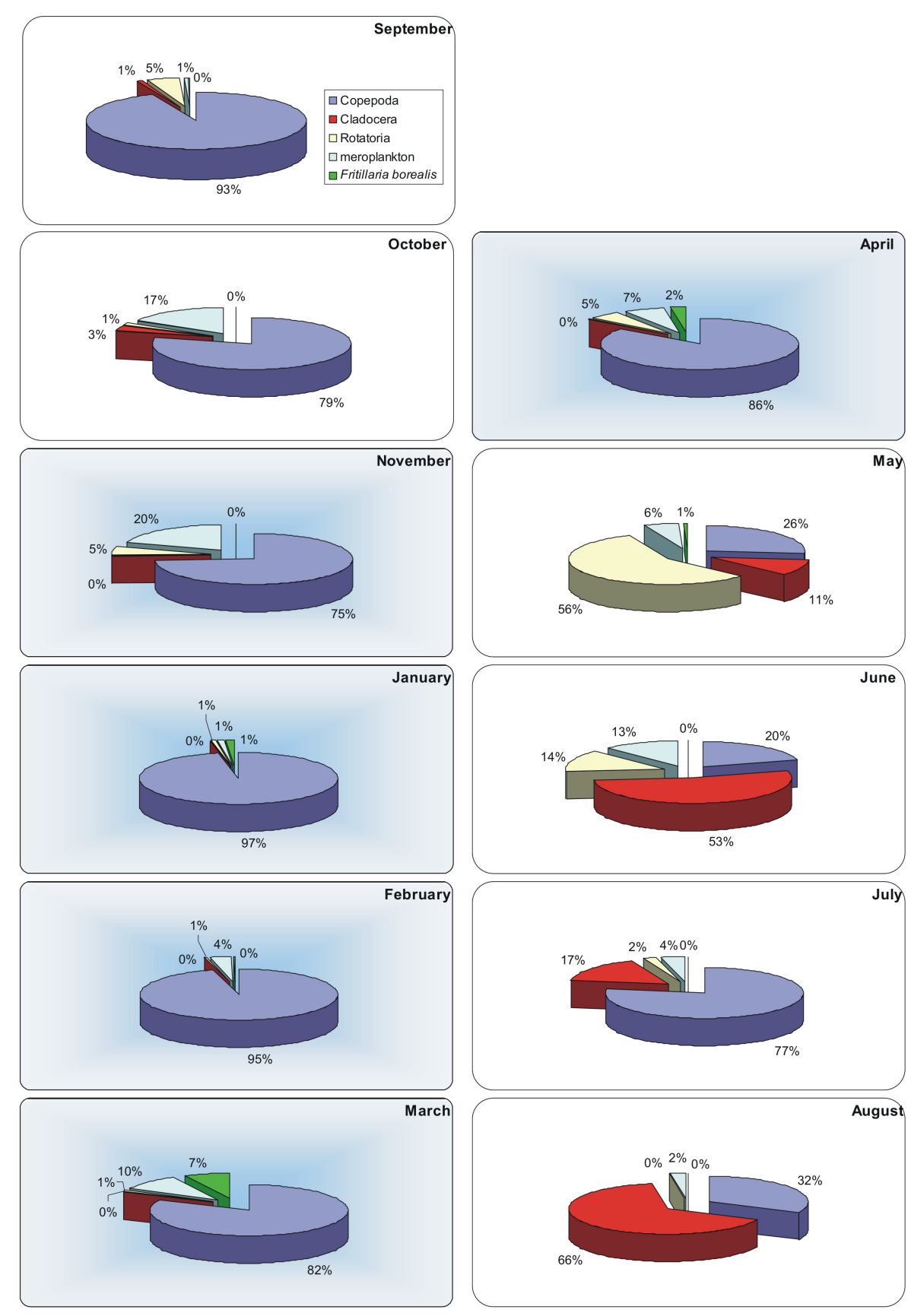

Fig. 7. Seasonal variability of biomass structure of zooplankton in the Gulf of Gdansk from September 1999 to August 2000 (blue - months of stagnancy period) (Mudrak, 2004).

in phytoplankton biomass and then in pelagic detritus concentration, which thereafter fall as a result of the increase in zooplankton (Fig. 4f) and Acartia spp. (Fig. 5) biomasses. The growth of the total zooplankton biomass mostly depend on food. Generally speaking, the numbers of zooplankton in the upper layer are the highest, when the algal biomass and pelagic detritus concentrations there are large. However, the later increase in Acartia spp. is caused by the increase in biomass of successive stages. This situation led to the substantial growth in the total biomass of Acartia spp., which is the algebraic sum of the products of weights $W_{i}$ and numbers $Z_{i}$ for modeled stages $\left(Z_{\text {Acartia }}=\sum_{i=\text { stages }} W_{i} Z_{i}\right)$. These small maxima occurring in the distribution $Z_{\text {Acartia }}$ are the result mainly of egg production by each adult causing their numbers $Z_{i}$ to increase. 


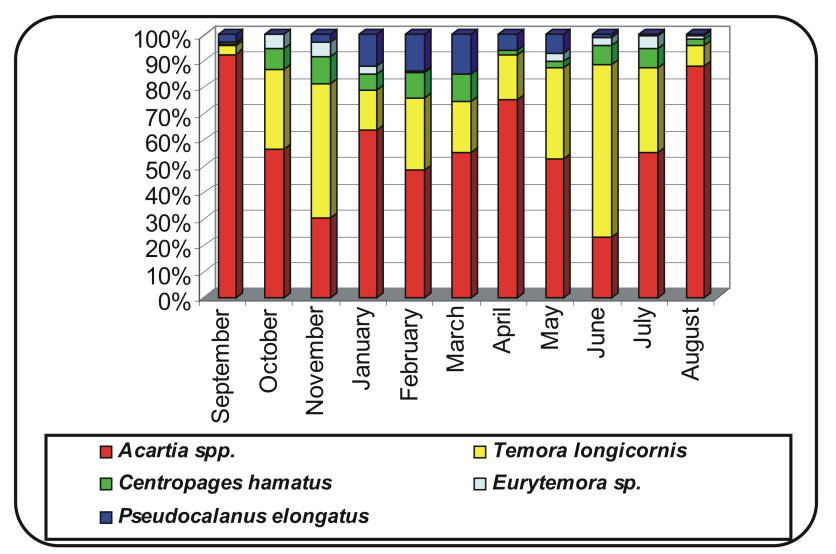

Fig. 8. Taxonomical structure of Copepoda in the Gulf of Gdansk from September 1999 to August 2000 (biomass) (Mudrak, 2004).

The experimental data presented in the Subsect. 3.2 show the percentage contributions of the mezozooplanktonu and Copepoda components and also refer to important mezozooplankton taxa for comparison of the modeled total zooplankton biomass to experimental results and of taxonomical structure of important Copepoda to Acartia spp. An analysis of these information and those given in Mudrak (2004) demonstrate, that the experimental total mezozooplankton biomass was characterized by two biomass peaks in a year, in June (ca. $130 \mathrm{mg} \mathrm{C} \mathrm{m}^{-3}$ ) and August (ca. $80 \mathrm{mg} \mathrm{C} \mathrm{m}^{-3}$ ), similar to the modeled zooplankton. These values are slightly lower than those of the total zooplankton biomass, which was modeled using the bulk formation because the microzooplankton biomass was not included in the experimental data. In this model, the total zooplankton is represented by microand mezozooplankton. The differences between the modeled and mean observed values are equal to $20-50 \%$ depend on the month for which the calculations were made, stations at which the plankton material was collected as well on the $\mathrm{gC} / \mathrm{g}_{\mathrm{w} . \mathrm{w}}$. ratio for converting the simulated organic carbon contents to wet weight. In this paper, the calculations were made assuming the $\mathrm{gC} / \mathrm{g}_{\mathrm{w} . w}$. ratio as 0.064 after Vinogradov and Shushkina (1993). The experimental data were used as the climatology because they were the only data available for that purpose.

The influence of temperature and food concentration on the development of each of the model stages is similar, as described in Dzierzbicka-Glowacka et al. (2009). The annual cycle of the total biomass of Acartia spp. is the result of the above-mentioned parameters, but mainly due to temperature changes. Figure 9 shows the results of numerical simulations and observed data for three successive regions of Gdansk Gulf for total biomass of Acartia spp. (in $\mathrm{mg} \mathrm{C} \mathrm{m}^{-3}$ ) as monthly averages in the upper $20 \mathrm{~m}$ layer. The highest values of Acartia spp. modeled biomass in 2000 occur in the period of high temperatures, in summer, and in July and August were ca. 30 and $40 \mathrm{mg} \mathrm{C} \mathrm{m}^{-3}$, respectively. The values

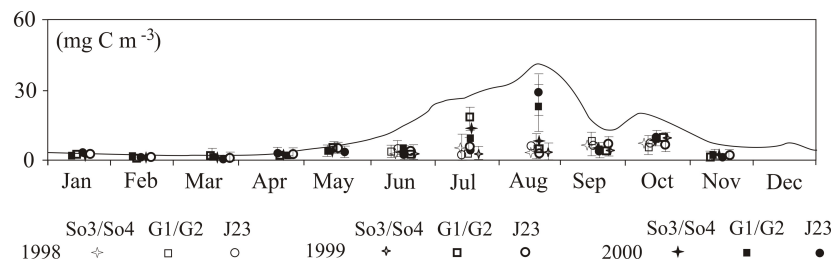

Fig. 9. Observed Acartia spp. biomass for the Gdansk Gulf compared to simulated population (solid line) - based surface biomass

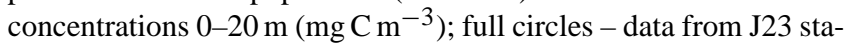
tion, full squares - data from G1 and G2 stations, full stars - data from So3 and So4 stations from 2000; half-open circles - data from J23 station, half-open squares - data from G1 and G2 stations, halfopen stars - data from So3 and So4 stations from 1999; open circles - data from J23 station, open squares - data from G1 and G2 stations, open stars - data from So3 and So4 stations from 1998.

were higher in August than July as a result of higher temperatures. In all the months, the mean observed values are lower than the means obtained by the model; however, in August in 2000 , the experimental data are closest to the mean numerical results.

The modeled total biomass of Acartia spp. at P1 in 1999 was characterized by two biomass peaks, the main one in July, and a smaller one in September (Dzierzbicka-Glowacka et al., 2006) similar to the experimental data. In 1999, only two complete distinct generations, from eggs to adults, developed throughout the year, one beginning in April and the other from mid-June to mid-July as the result of the lower temperature at the Gdansk Deep (in the open sea) than both in the same area in 2000 and inside the bay (Mudrak, 2004) in the same year 1999. Another reason for that could be the parametrisation in the previous versions of population model used in Dzierzbicka-Glowacka et al. (2006), which was not complete.

However, in the south-eastern Baltic Sea, one complete generation of Pseudocalanus minutus elongatus develops in spring, summer and early autumn. In 1999 at P1, it developed throughout the seven mouths, beginning in mid-April and ending in mid-November. The modeled total depth integrated biomass of Pseudocalanus was characterized by one peak biomass, at the turn of June and July (DzierzbickaGlowacka et al., 2006).

The significant difference in development between the two species is mainly the result of the low salinity in the Baltic Sea. P. minutus elongatus is quite euryhaline or properly marine euryhaline; its lower salinity toleration is 4-5 PSU after Kinne (1963) and 7.25 PSU after Postel (2005). The biomass of $P$. $m$. elongatus from the Baltic Sea is largely dependent on salinity (Möllmann et al., 2000) and decreases with diminishing salinity. According to the findings of a previous study (Dzierzbicka-Glowacka, 2004), it appears that the maximum growth rate of $P$. m. elongatus from the Baltic Sea (Gdansk Deep, $11 \mathrm{PSU}$ salinity) at $5{ }^{\circ} \mathrm{C}$ is about half that 
of P. elongatus from the North Sea for small copepods, but is about three times lower for the largest ones.

Shallow coastal waters, particularly in sheltered bays and near river mouths, fertilized by the influence of rivers and organic pollutants entering the sea, are the areas richest in zooplankton in the Southern Baltic Sea (Chojnacki and Antonczak, 2008). The water temperature is lower in the coastal region than in the open sea when upwelling appears. In such a case, higher temperature and salinity of water at the Gdansk Deep (in the open sea) are more favourable conditions for development of copepods, mainly of Pseudocalanus m. elongatus. Hence, the Gdansk Gulf area partly is representative of the south-eastern Baltic Sea but contrary to the Gdansk Deep, in context of the ecological shifts already documented in the area except euryhaline species, which development is largely dependent on salinity as Pseudocalanus m. elongatus.

The next step in our modeling work is to run the population model within an ecosystem model to study the impact of seasonal variations of food and temperature on T. longicornis biomass in the South-Eastern Baltic Sea. Most of the coefficients used in the model will be taken from the literature, containing values from various published studies and parameters derived for similar species. This approach is possible, because the species is not much sensitive to the differences in the salinity, similarly as some species Acartia but contrary to Pseudocalanus minutus elongatus. Development and growth of Temora longicornis using the duration of each of the model stages was calculated in another study (which has been submitted as a separate paper), as a function of both food concentration from $25 \mathrm{mg} \mathrm{C} \mathrm{m}^{-3}$ to excess and temperature in the $5-20^{\circ} \mathrm{C}$ range from laboratory experiments after Klein Breteler and Gonzalez (Klein Breteler and Gonzalez, 1986).

Also, a following step in our modeling work is to add into the model several species of calanoid copepods (Pseudocalanus m. elongatus, Acartia spp. and Temora longicornis) presenting contrasted life-cycle strategies and compare their respective population dynamics, and the benefits (and/or drawbacks) of trading the bulk zooplankton for a more detailed and complex zooplankton community (e.g. Ji et al., 2009). As well, we intend to study the impact of climate changes on the development of the investigated copepods in the South-Eastern Baltic Sea through the impact of seasonal variations of food, temperature and salinity within the next few decades. This has not yet been investigated and the response of the marine ecosystem is unknown. The numerical models are actually one of the most efficient way to integrate and summarize large amount of observation data collected through much money, effort and patience, as well as generating new knowledge about the subject of the study.

Acknowledgements. This research was carried out in support of a grant of the Polish State Committee of Scientific Research (No NN306 353239).

Edited by: F. Chai

\section{References}

Ambler, J. W.: Seasonal factors affecting egg production and viability of eggs of Acartia tonsa Dana, from East Lagoon, Galveston, Texas, Estuar. Coast. Shelf S., 20, 743-760, 1985.

Carlotti, F. and Sciandra, A.: Population dynamics model of Euterpina acutifrons (Copepoda: Harpacticoida) couplong individual growth and larval development, Mar. Ecol.-Prog. Ser., 56, 225242, 1989.

Carlotti, F. and Nival, P.: Model of copepod growth and development: moulting and mortality in relation to physiological processes during an individual moult cycle, Mar. Ecol.-Prog. Ser., 84, 219-233, 1992.

Carlotti, F. and Radach, G.: Seasonal dynamics of phytoplankton and Calanus finmarchicus in the North Sea as revealed by a coupled one-dimensional model, Limnol. Oceanogr., 41(3), 522539, 1996.

Carlotti, F. and Wolf, K. U.: A Lagrangian ensemble model of Calanus finmarchicus coupled with a 1-D ecosystem model, Fish. Oceanogr., 7(3/4), 191-204, 1998.

Chojnacki, J. C. and Antonczak, E.: Seasonal changes in the neritic zone mezozooplankton of Pomeranian Bay in 2000, available online: http://www.ejpau.media.pl/volume11/issue4/art-29. html, last access: July 2010, EJPAU 11(4), 29, 2008.

Ciszewski, P. and Witek, Z.: Production of older stages of copepods Acartia bifilosa Giesb. and Pseudocalanus elongatus Boeck in Gdansk Bay, Pol. Arch. Hydrobiol., 24, 449-459, 1977.

Dzierzbicka-Glowacka, L.: Growth and development of copepodite stages of Pseudocalanus spp., J. Plankton Res., 26, 49-60, 2004a.

Dzierzbicka-Glowacka, L.: A numerical investigation of phytoplankton and Pseudocalanus elongatus dynamics in the spring bloom time in the Gdansk Gulf, J. Mar. Syst., 53, 19-36, 2005a.

Dzierzbicka-Glowacka, L.: Modelling the seasonal dynamics of marine plankton in southern Baltic Sea, Part 1: A Coupled Ecosystem Model, Oceanologia, 47(4), 591-619, 2005 b.

Dzierzbicka-Glowacka, L.: Modelling the seasonal dynamics of marine plankton in the southern Baltic Sea, Part 2: Numerical simulations, Oceanologia, 48(1), 41-71, 2006.

Dzierzbicka-Glowacka, L., Lemieszek, A., and Żmijewska, I. M.: Parameterization of a population model for Acartia spp. in the southern Baltic Sea, Part 1: Development time, Oceanologia, 51(2), 165-184, 2009a.

Dzierzbicka-Glowacka, L., Lemieszek, A., and Żmijewska, I. M.: Parameterization of a population model for Acartia spp. in the southern Baltic Sea, Part 2: Egg production, Oceanologia, 51(2), 185-201, 2009b.

Dzierzbicka-Glowacka, L., Kulinski K., Maciejewska, A. and Pempkowiak J.: Particulate Organic carbon in the southern Balic Sea, Numerical simulations and experimental data, Oceanologia, submitted, 2010.

Fennel, W.: Modeling of copepods with links to circulation model, J. Plankton Res., 23, 1217-1232, 2001.

Fransz, H. G., Colebrook, J. M., Gamble, J. C., and Krause, M.: The zooplankton of the North Sea, Neth. J. Sea Res., 28(1/2), $1-52,1991$.

Katajisto, T.: Benthic resting eggs in the life cycles of calanoid copepods in the northern Baltic Sea, Walter and Andree de Nottbeck Foundation Scientific Rep. No. 29, Helsinki, Finland, 146, 2006. 
Last, J. M.: The food of twenty species of fish larvae in the westcentral North Sea, Fisheries Research Technical report, Lowestoft, 60, 44 pp., 1980.

Maritime Branch Materials Institute of Meteorology and Water Management: Environmental conditions in the Polish zone of the southern Baltic Sea during 1999, IMGW Gdynia, Institute of Meteorology and Water Management in Gdynia, Poland, 299 pp., 2000.

Mauchline, J.: The Biology of Calanoid Copepods, Academic Press, San Diego, USA, 710 pp., 1998.

McLaren, I. A.: Generation lengths of some temperate marine copepods: estimation, production and implications, J. Fish Res. Bd. Can., 345, 1330-1342, 1978.

McLaren, I. A. and Leonard, A.: Assessing the equivalence of growth and egg production of copepods, ICES J. Mar. Sci., 52, 397-408, 1995.

Moll, A. and Stegert, C.: Modelling Pseudocalanus elongates stage-structured population dynamics embedded in a water column ecosystem model for the northern North Sea, J. Mar. Syst., 64, 35-46, 2007.

Mudrak, S.: Short- and long-term variability of zooplankton in coastal Baltic waters: using the Gulf of Gdansk as an example, PhD Thesis, Gdansk University, Gdynia, Gdansk, Poland, 328 pp.+Aneks, 2004.

Mudrak, S. and Żmijewska, M. I.: Spatio-temporal variability of mesozooplankton from the Gulf of Gdansk (Baltic Sea) in 19992000, Oceanol. Hydrobiol. Stud., 36(2), 3-19, 2007.

Norrbin, M. F.: Timing of diapause in relation to the onset of winter in the high-latitude copepods Pseudocalanus acuspes and Acartia longiremis, Mar. Ecol.-Prog. Ser., 142, 99-109, 1996.
Postel, L.: Habitat layer extension and the occurrence of dominant calanoid copepods in the Baltic Sea, available online: http://www.helcom.fi/BSAP_assessment/ifs/archive/ifs2005/ en_GB/zooplankton/, last access: July 2010, 2005.

Sekiguchi, H., McLaren, I. A., and Corkett, C. J.: Relationship between growth rate and egg production in the copepod Acartia clausi Hudsonica, Mar. Biol., 58, 133-138, 1980.

Stegert, C., Kreus, M., Carlotii, F., and Moll, A.: Parameterisation of a zooplankton population model for Pseudocalanus elongatus using stage durations from laboratory experiments, Ecol. Model., 206, 213-230, 2007.

Wiktor, K.: Zooplankton biomass in the coastal waters of Gdansk Gulf, Oceanography, 12, 109-134, 1990.

Wiktor, K. and Żmijewska, M. I.: Zooplankton species composition and distribution in the waters of the inshore part of the Gulf of Gdansk, Stud. Mater. Oceanol., 46, 64-114, 1985.

Wroblewski, J. S. and Richman, J. G.: The non-linear response of plankton to wind mixing events - implications for survival of larval northern anchovy, J. Plankton Res., 9, 103-123, 1987.

Viitasalo, M.: Calanoid resting eggs in the Baltic Sea: implications for the population dynamics of Acartia bifi losa (Copepoda), Mar. Biol., 114, 397-405, 1992.

Vinogradow, M. E. and Shushkina, E. A.: Functioning of plankton communities in the euphotic zone of the ocean, Nauka, Moskwa, Russia, 1987.

Voipio, A.: The Baltic Sea, Elsevier Scientific Publishing Company, Amsterdam, The Netherlands, 123-143, 1981. 